\title{
Review of "School Industry Links: The Consequences of Minding Other People's Business"
}

\author{
Jan Wright \\ University of Wollongong
}

Price, Bronte (1991). School Industry Links: The Consequences of Minding Other People's Business. Australian Education Review No. 34. Hawthorn, Vic: Australian Council for Educational Research. ISBN 0864311001.

In Australia and in most western English speaking countries recent education policy has made a major shift away from a liberal-humanist general education towards a more vocationally oriented curriculum which is responsive to national economic goals. Within this context there has been a push from educational authorities and the government to make education more responsive to 'the needs of industry'. School industry link programs have developed as an expression of this policy direction.

Bronte Price makes an important and timely contribution to the growing literature on school industry links. Two outstanding feature of the book which make it immensely valuable reading are its focus on educational goals and its commitment to social justice and equity. Both of which can be too easily lost in the interests of productivity and meeting industry interests. Price puts the student at the centre of the learning process not just as the location where specific skills and competencies are acquired but as a participant in collaborative decision making, active problem-solving and inquiry-based learning. The combination of student-centred learning in a work and community context goes back to John Dewey, however in the current context of education with its emphasis on instrumental outcomes and skill acquisition Price's vision becomes utopian. Moreover it extends the notion of industry to cover links with unions and unionists and with those who are in unpaid work.

The first section of the book is devoted to a critical discussion of the principles and issues associated with school industry link programs. Price provides a brief but very useful historical and social context to explain the 
development and need for closer links between schools and the world of work. He argues that both teachers and employers carry out-dated attitudes and perceptions of each others areas of knowledge and practice. School industry links provide the means by which teachers and students can have access to more accurate information about various types of work and the labour market. At the same time industry may be less ready to level criticisms at teachers if they were better informed of current developments in curriculum and pedagogy.

The major portion of the book is devoted to the ways in which school industry links may be implemented. This includes very detailed descriptions and critical reviews of specific strategies which have been tried in Australia and overseas. These include teacher placement in industry, twinning, compacts, the participation of adults other than teachers, curriculum-based visits to industry, work experience and minienterprise. Not all are recommended for implementation in Australia. For instance, the practice of "compacts" which involves commitments by industry to employ school leavers who reach specific compact goals is questioned on social justice and educational grounds. The section on the strategy of "work experience" provides several very useful alternatives to the traditional work experience model which has come under so much criticism from students, teachers and industry personnel.

For Price the only truly successful model of school industry links is one where industry links are integrated into the curriculum.

School industry links is not just another piece of content to be added to the curriculum sandwich. It is a methodology, a different way of viewing the world, of adding richness to the curriculum by adopting a different perspective.(p.59)

He provides a detailed description of ways to implement work-related units, together with an imaginative checklist of evidence against which to judge the degree to which integration has occurred.

The books finishes with hypothetical scenarios of school industry links from the perspective of a student, a teacher, a parent/employer and a unionist. It is here that Price is at his most visionary and persuasive, but perhaps most difficult to accept. In comparison to the real life case studies as reported in the national Connections Project, the way for Price's participants is far too smooth.

I do have one other minor criticism. Although reasonably even-handed in attributing negatives attitudes, out-dated perceptions and reluctance to participate in schools link programs to both industry personnel and teachers, teachers' integrity and their right to a dissenting voice are underestimated and at times denigrated. For instance, in discussing 
reasons for teachers' reluctance to be involved in school industry links, Price concludes that other factors "may mask two other fears that teachers can have, namely, fear of people and fear of failure" (p.26). No such personal attributions are levied at any other participants mentioned in the book. In the real world of policy making informed by national economic goals, teachers and schools may very rightly be reluctant to enter into associations with industry where they may be the subordinate partner. Forging successful links with schools that are mutually beneficial is a difficult and time consuming process that requires an ongoing commitment on all sides, including practical support from education authorities.

School Industry Links is mandatory reading for anyone considering initiating or continuing a link program. The detailed descriptions of how a curriculum and pedagogy could look if everybody involved in the education of students were working towards the same educational outcomes provide a yardstick against which existing and proposed programs can be compared and evaluated.

Please cite as: Wright, J. (1992). Review of "School Industry Links: The Consequences of Minding Other People's Business". Australian Journal of Educational Technology, 8(1), 82-84.

http:/ / www.ascilite.org.au/ajet/ajet8/wright.html 